Thromb Res. 2012 May ; 129(Suppl 2): S18-S20. doi:10.1016/j.thromres.2012.02.022.

\title{
Decryption of tissue factor
}

\author{
Saulius Butenas* and Jolanta Krudysz-Amblo \\ University of Vermont, Department of Biochemistry, Burlington, VT, USA
}

\begin{abstract}
Tissue factor (TF) is a transmembrane protein which, in complex with factor (F)VIIa, initiates blood coagulation. Numerous studies have determined TF epitopes and individual amino acids which play an important role in the TF/FVIIa complex formation and its activity towards natural substrates. However the subject of cell-surface TF activity remains controversial. It has been almost commonly accepted that TF on the cell surface has low (if any) activity, i.e. is encrypted and requires specific conditions/reagents to become active, i.e. decrypted. One of the leading theories suggests that cell membrane lipid composition plays a crucial role in TF decryption, whereas another assigns the key role to the formation of the Cys ${ }^{186}-\mathrm{Cys}^{209}$ disulfide bond. Despite a number of studies published from several laboratories, the role of this bond in the activity of the TF/FVIIa complex remains elusive and controversial. One of the causes of this controversy could be related to the lack of specificity of the reagents used for the cell treatment leading to possible alterations in other cell surface proteins and cell membrane environment. In conclusion, the influence of the Cys ${ }^{186}$ - $\mathrm{Cys}^{209}$ this bond on cell surface TF function remains unclear.
\end{abstract}

\section{Keywords}

Tissue factor; Disulfide formation; Protein disulfide isomerase; Mercuric chloride; Acidic phospholipids

\section{Activity of tissue factor}

Tissue factor is a transmembrane protein expressed in various cells and found at the highest concentrations in brain, lungs and placenta[1-3]. Upon vascular injury or agonist stimulation (primarily with inflammation-related cytokines), tissue factor becomes exposed to the blood flow, binds circulating factor VIIa and initiates processes leading to thrombin generation and clot formation[4-7]. In healthy individuals with no pathologic conditions, there is no detectable active tissue factor present in contact with blood[8-10]. Tissue factor by itself has no proteolytic/amidolytic activity but increases activity of factor VIIa by several orders of magnitude upon the factor VIIa/tissue factor complex formation[11, 12]. Binding of tissue factor to factor VIIa is calcium-dependent, although the enzymatic complex of these two proteins can be formed in the absence of divalent metal ions as well[11, 12]. However, the affinity of this complex in the absence of calcium ions is quite low. The activity of the factor

(C) 2012 Elsevier Ltd. All rights reserved.

*Corresponding author. University of Vermont, Department of Biochemistry, 208 South Park Drive, Room 235A, Colchester, VT 05446, USA. Tel: +1-802-656-0350, fax:+1-802-656-2256. sbutenas@uvm.edu (S. Butenas).

Publisher's Disclaimer: This is a PDF file of an unedited manuscript that has been accepted for publication. As a service to our customers we are providing this early version of the manuscript. The manuscript will undergo copyediting, typesetting, and review of the resulting proof before it is published in its final citable form. Please note that during the production process errors may be discovered which could affect the content, and all legal disclaimers that apply to the journal pertain.

Conflict of interest statement

None declared. 
VIIa/tissue factor complex can be divided into surface-independent and surface-dependent. The former group of reactions occurs in solution and is characteristic for low molecular weight substrates, which bind directly to the active site of factor VIIa. In these reactions, tissue factor increases amidolytic activity of factor VIIa by 1-2 orders of magnitude[12-14] and localization of the factor VIIa/tissue factor complex on the membrane surface does not influence amidolytic activity of the complex[15]. However for the physiologically-relevant proteolysis of natural substrates of the factor VIIa/tissue factor complex (factors IX, X and VII), anchoring of the complex to the membrane surface by tissue factor becomes essential[16, 17]. The complex formed by factor VIIa and tissue factor proteins lacking the ability to bind to the membrane cannot efficiently (if at all) proteolyze its natural substrates and could become an inhibitor of blood coagulation by tightening circulating factor VIIa into an inefficient complex[18]. Although there is a common agreement about an essential role of the membrane surface, particularly of the cell membrane, for tissue factor activity in vivo, the mechanism regulating activity of cell tissue factor has been a subject of discussion for the last two decades.

\section{Decryption of tissue factor}

The prevailing hypothesis related to cell tissue factor activity is that many cells, including those in contact with blood, contain tissue factor on their surface. However under normal physiologic conditions that tissue factor is not active, i.e. "encrypted", and needs "decryption" to express the procoagulant activity[19].Several mechanisms, often contradictory, have been hypothesized in attempts to explain "encryption-decryption" of tissue factor activity.

One of the suggested methods for the decryption of tissue factor on the cell surface consists of the treatment of tissue factor-bearing cells with calcium ionophore[20-26]. Upon such treatment, calcium ions are released from the internal stores followed by the influx of extracellular calcium across the membrane leading to an increase in the concentration of cytosolic calcium ions. Suggested increases in cell surface tissue factor activity, caused by the calcium ionophore treatment, range from 2 to 10 -fold. However other studies assign this calcium ionophore-induced increase in tissue factor activity to an increased expression of tissue factor protein[20] or to changes in the cell membrane environment, particularly in an increased expression of acidic phospholipids [21, 23], 26]. In some studies, changes observed in the cell membrane environment are associated with the cell death[22, 25]. A few studies published from several laboratories suggested a role for the cell membrane lipid rafts, particularly for cholesterol accumulated in those rafts, as contributors to the encryption-decryption of tissue factor activity[27-29], although there are certain discrepancies between the observed results and suggested mechanisms for this process. An increase in tissue factor activity has been reported when lipopolysaccharide-stimulated monocytes were treated with platelets[30-32]. This observed increase in activity was quite limited ( 2 to 3 -fold) and could be (at least in part) assigned to an increase in tissue factor antigen expression by monocytes[32].

In our laboratory we investigated the subject of tissue factor encryption-decryption quantitating tissue factor antigen and activity on blood monocytes and platelets, and cultured monocytic cells and purified platelets[9]. No tissue factor antigen or activity was observed on non-stimulated cells. Upon the stimulation of purified monocytic cells with lipopolysacchrides, the vast majority of them expressed both tissue factor antigen and activity. Changes in antigen concentration over time overlapped with the changes in activity (Figure 1), suggesting that no decryption was required to explain the increase in tissue factor activity upon stimulation. No tissue factor antigen or activity was observed on platelets stimulated either in blood or in a buffer environment[9]. Publications from several other 
laboratories also showed a correlation between the tissue factor antigen expression and its activity on cell surface[33-35] raising a question whether tissue factor decryption is common for all cells or it is a property of certain cell types only.

\section{Oxidation/reduction of cysteines}

It has been suggested by several groups of investigators that cell surface tissue factor decryption is related to the $\mathrm{Cys}^{186}-\mathrm{Cys}^{209}$ disulfide bond formation. The key data leading to this hypothesis were based on the mutational studies by Edgington's group[36]. The authors mutated either $\mathrm{Cys}^{49}$ and $\mathrm{Cys}^{57}$ (which potentially could form a disulfide bridge in the Nterminal part of the extracellular domain of tissue factor) or $\mathrm{Cys}^{186}$ and $\mathrm{Cys}^{209}$ (which could form a disulfide bond in the vicinity of the membrane) substituting them with serine residues. Mutations of $\mathrm{Cys}^{49}$ and $\mathrm{Cys}^{57}$ had no effect on activity of the factor VIIa/tissue factor complex (extrinsic factor Xase), whereas mutations of Cys ${ }^{186}$ and Cys ${ }^{209}$ decreased the activity of this complex by approximately 3 -fold due to an impaired binding of factor VIIa to this tissue factor mutant. Based on these data it was concluded that the N-terminal pair of cysteines plays no role in tissue factor activity, whereas the disulfide bridge in the Cterminus of the extracellular domain is essential for the decryption of tissue factor. However, the Cys186Ser and Cys209Ser mutant, in contrast to the wild-type protein and Cys49Ser and Cys57Ser mutant, lacked glycosylation, which could be the contributing factor to reduced tissue factor activity[37].

The role of the Cys ${ }^{186}$-Cys ${ }^{209}$ disulfide in the regulation of cell-surface tissue factor has been the subject of debates for the last several years. An increased tissue factor activity has been suggested upon the treatment of cells with mercuric chloride, an oxidizing agent[38]. The authors concluded that this reagent restores the $\mathrm{Cys}^{186}{ }^{18 y s^{209}}$ disulfide bond leading to the observed changes in tissue factor activity. However, no data (experimental or theoretical) are provided supporting the re-formation of the disulfide bridge hypothetically present in a reduced form on untreated cells. Existing publications related to the protein treatment with mercuric chloride show that it oxidizes only a single thiol group $[39,40]$ and that a similar effect could be achieved by treating tissue factor-bearing cells with other metal compounds[41].

In several publications from the laboratory of $\mathrm{W}$. Ruf, it has been suggested that protein disulfide isomerase (PDI) is responsible for the regulation of cell tissue factor activity via its effect on Cys ${ }^{186}$-Cys ${ }^{209}$ disulfide bond oxidation/reduction[42-44]. Similarly, studies from the laboratory of B. Engelmann proposed that tissue factor activation by PDI occurs due to the isomerization of a mixed disulfide and an intramolecular Cys ${ }^{186}-$ Cys $^{209}$ bond formation[45, 46]. In contrast to these publications, data acquired in several other laboratories showed that the tissue factor activity-enhancing effect of PDI is related to the presence of acidic phospholipids either as a contaminant in the PDI preparations [47, 48] or due to its relocation to the tissue factor-bearing cell surface upon treatment with PDI or mercuric chloride[49-52]. Moreover, Bach and Monroe suggested that Cys ${ }^{186}$ and Cys ${ }^{209}$ are not available for interaction with PDI when tissue factor is bound to factor VIIa, i.e. at physiologically relevant conditions[53]. Lately, it has been suggested in a report published by Kothari et al. that the Cys ${ }^{186}-\mathrm{Cys}^{209}$ disulfide bond is not essential for the cell tissue factor procoagulant activity[54].

There are several possible explanations for the contradictions observed in publications describing the influence of PDI on tissue factor activity: 1) a variability of reagents and procedures used in different laboratories; 2) the use of different cell lines; and 3) the lack of specificity of PDI for tissue factor. In addition to the effect on cell membrane lipid composition[50, 51], PDI targets multiple proteins in the cell, catalyzing thiol-disulfide 
exchange[55-57]. Both of those processes could alter tissue factor activity without changing the status of thiols/disulfides. Additionally, PDI can alter thrombin generation in a tissue factor-independent manner via coagulation factor ligation to platelets[58] or by catalyzing complex formation with participation of thrombin and antithrombin[59].

\section{Conclusion}

The subject of tissue factor encryption-decryption in general and the role of the Cys ${ }^{186}$ $\mathrm{Cys}^{209}$ disulfide bond in that process in particular remains controversial, and further studies are necessary to resolve this conundrum.

\section{Acknowledgments}

This work was supported by the P01 HL46703 grant from the National Institutes of Health.

\section{References}

1. Drake TA, Morrissey JH, Edgington TS. Selective cellular expression of tissue factor in human tissues. Implications for disorders of hemostasis and thrombosis. Am J Pathol. 1989; 134:10871097. [PubMed: 2719077]

2. Fleck RARL, Rapaport SI, Varki N. Localization of human tissue factor antigen by immunostaining with monospecific, polyclonal anti-human tissue factor antibody (corrected and republished article originally printed in Thromb. Res. 1990 Mar. 1;57(5)765-81). Thromb Res. 1990; 59:421-437. [PubMed: 2237820]

3. Eddleston M, de la Torre JC, Oldstone MB, Loskutoff DJ, Edgington TS, Mackman N. Astrocytes are the primary source of tissue factor in the murine central nervous system. A role for astrocytes in cerebral hemostasis. J Clin Invest. 1993; 92:349-358. [PubMed: 8326003]

4. Kornberg A, Rahimi-Levene N, Yona R, Mor A, Rachmilewitz EA. Enhanced generation of monocyte tissue factor and increased plasma prothrombin fragment $1+2$ levels in patients with polycythemia vera: mechanism of activation of blood coagulation. Am J Hematol. 1997; 56:5-11. [PubMed: 9298860]

5. Nijziel M, van Oerle R, van 't Veer C, van Pampus E, Lindhout T, Hamulyak K. Tissue factor activity in human monocytes is regulated by plasma: implications for the high and low responder phenomenon. Br J Haematol. 2001; 112:98-104. [PubMed: 11167790]

6. Broussas M, Cornillet-Lefebvre P, Potron G, Nguyen P. Adenosine inhibits tissue factor expression by LPS-stimulated human monocytes: involvement of the A3 adenosine receptor. Thromb Haemost. 2002; 88:123-130. [PubMed: 12152652]

7. Butenas S, Orfeo T, Mann KG. Tissue factor in coagulation: Which? Where? When? Arterioscler Thromb Vasc Biol. 2009; 29:1989-1996. [PubMed: 19592470]

8. Osterud B. Tissue factor expression in blood cells. Thromb Res. 2010; 125(Suppl 1):S31-S34. [PubMed: 20149415]

9. Butenas S, Bouchard BA, Brummel-Ziedins KE, Parhami-Seren B, Mann KG. Tissue factor activity in whole blood. Blood. 2005; 105:2764-2770. [PubMed: 15604222]

10. Butenas S, Mann KG. Active tissue factor in blood? Nat Med. 2004; 10:1155-1156. author reply 6. [PubMed: 15516902]

11. Komiyama Y, Pedersen AH, Kisiel W. Proteolytic activation of human factors IX and X by recombinant human factor VIIa: effects of calcium, phospholipids, and tissue factor. Biochemistry. 1990; 29:9418-9425. [PubMed: 2248955]

12. Butenas S, Lawson JH, Kalafatis M, Mann KG. Cooperative interaction of divalent metal ions, substrate, and tissue factor with factor VIIa. Biochemistry. 1994; 33:3449-3456. [PubMed: 8136382]

13. Krishnaswamy S. The interaction of human factor VIIa with tissue factor. J Biol Chem. 1992; 267:23696-23706. [PubMed: 1429710] 
14. Butenas S, Ribarik N, Mann KG. Synthetic substrates for human factor VIIa and factor VIIa-tissue factor. Biochemistry. 1993; 32:6531-6538. [PubMed: 8329383]

15. Lawson JH, Butenas S, Mann KG. The evaluation of complex-dependent alterations in human factor VIIa. J Biol Chem. 1992; 267:4834-4843. [PubMed: 1537862]

16. Krishnaswamy S, Field KA, Edgington TS, Morrissey JH, Mann KG. Role of the membrane surface in the activation of human coagulation factor X. J Biol Chem. 1992; 267:26110-26120. [PubMed: 1464622]

17. Morrissey JH, Macik BG, Neuenschwander PF, Comp PC. Quantitation of activated factor VII levels in plasma using a tissue factor mutant selectively deficient in promoting factor VII activation. Blood. 1993; 81:734-744. [PubMed: 8427965]

18. Butenas SOT, Brummel-Ziedins KE, Mann KG. Membrane-Bound and Soluble Tissue Factor Fuse and Fire Extinguisher; Abstract \#123. Blood. 2004; 104:39a.

19. Bach RR. Tissue factor encryption. Arterioscler Thromb Vasc Biol. 2006; 26:456-461. [PubMed: 16397140]

20. Wakita K, Stearns-Kurosawa DJ, Marumoto Y. The effect of calcium ionophore A23187 on tissue factor activity and mRNA in endothelial cells. Thromb Res. 1994; 74:95-103. [PubMed: 8029820]

21. Bach R, Rifkin DB. Expression of tissue factor procoagulant activity: regulation by cytosolic calcium. Proc Natl Acad Sci U S A. 1990; 87:6995-6999. [PubMed: 2119499]

22. Henriksson CE, Klingenberg O, Hellum M, Landsverk KS, Joo GB, Westvik AB, et al. Calcium ionophore-induced de-encryption of tissue factor in monocytes is associated with extensive cell death. Thromb Res. 2007; 119:621-630. [PubMed: 16844202]

23. Stampfuss JJ, Censarek P, Bein D, Schror K, Grandoch M, Naber C, et al. Membrane environment rather than tissue factor expression determines thrombin formation triggered by monocytic cells undergoing apoptosis. J Leukoc Biol. 2008; 83:1379-1381. [PubMed: 18305177]

24. Carson SD, Perry GA, Pirruccello SJ. Fibroblast tissue factor: calcium and ionophore induce shape changes, release of membrane vesicles, and redistribution of tissue factor antigen in addition to increased procoagulant activity. Blood. 1994; 84:526-534. [PubMed: 8025281]

25. Henriksson CE, Hellum M, Landsverk KS, Klingenberg O, Joo GB, Kierulf P. Flow cytometrysorted non-viable endotoxin-treated human monocytes are strongly procoagulant. Thromb Haemost. 2006; 96:29-37. [PubMed: 16807648]

26. Rand ML, Wang H, Bang KW, Packham MA, Freedman J. Persistence of phosphatidylserine exposure on activated platelets in vivo in rabbits. Thromb Haemost. 2007; 98:477-478. [PubMed: 17721637]

27. Mandal SK, Iakhiaev A, Pendurthi UR, Rao LV. Acute cholesterol depletion impairs functional expression of tissue factor in fibroblasts: modulation of tissue factor activity by membrane cholesterol. Blood. 2005; 105:153-160. [PubMed: 15328160]

28. Dietzen DJ, Page KL, Tetzloff TA. Lipid rafts are necessary for tonic inhibition of cellular tissue factor procoagulant activity. Blood. 2004; 103:3038-3044. [PubMed: 15070681]

29. Liu ML, Reilly MP, Casasanto P, McKenzie SE, Williams KJ. Cholesterol enrichment of human monocyte/macrophages induces surface exposure of phosphatidylserine and the release of biologically-active tissue factor-positive microvesicles. Arterioscler Thromb Vasc Biol. 2007; 27:430-435. [PubMed: 17158353]

30. Lorenzet R, Niemetz J, Marcus AJ, Broekman MJ. Enhancement of mononuclear procoagulant activity by platelet 12-hydroxyeicosatetraenoic acid. J Clin Invest. 1986; 78:418-423. [PubMed: 3090104]

31. Halvorsen H, Olsen JO, Osterud B. Granulocytes enhance LPS-induced tissue factor activity in monocytes via an interaction with platelets. J Leukoc Biol. 1993; 54:275-282. [PubMed: 8409749]

32. Osterud B, Rao LV, Olsen JO. Induction of tissue factor expression in whole blood: lack of evidence for the presence of tissue factor expression in granulocytes. Thromb Haemost. 2000; 83:861-867. [PubMed: 10896239]

33. Mattsson E, Herwald H, Egesten A. Superantigens from Staphylococcus aureus induce procoagulant activity and monocyte tissue factor expression in whole blood and mononuclear cells via IL-1 beta. J Thromb Haemost. 2003; 1:2569-2576. [PubMed: 14675093] 
34. Zhou H, Wolberg AS, Roubey RA. Characterization of monocyte tissue factor activity induced by IgG antiphospholipid antibodies and inhibition by dilazep. Blood. 2004; 104:2353-2358. [PubMed: 15226179]

35. Vaidyula VR, Rao AK, Mozzoli M, Homko C, Cheung P, Boden G. Effects of hyperglycemia and hyperinsulinemia on circulating tissue factor procoagulant activity and platelet CD40 ligand. Diabetes. 2006; 55:202-208. [PubMed: 16380494]

36. Rehemtulla A, Ruf W, Edgington TS. The integrity of the cysteine 186-cysteine 209 bond of the second disulfide loop of tissue factor is required for binding of factor VII. J Biol Chem. 1991; 266:10294-10299. [PubMed: 2037582]

37. Krudysz-Amblo J, Jennings ME 2nd, Mann KG, Butenas S. Carbohydrates and activity of natural and recombinant tissue factor. J Biol Chem. 2010; 285:3371-3382. [PubMed: 19955571]

38. Chen VM, Ahamed J, Versteeg HH, Berndt MC, Ruf W, Hogg PJ. Evidence for activation of tissue factor by an allosteric disulfide bond. Biochemistry. 2006; 45:12020-12028. [PubMed: 17002301]

39. Bednar RA, Fried WB, Lock YW, Pramanik B. Chemical modification of chalcone isomerase by mercurials and tetrathionate. Evidence for a single cysteine residue in the active site. $\mathrm{J}$ Biol Chem. 1989; 264:14272-14276. [PubMed: 2760066]

40. Weber GJ, Mehr AP, Sirota JC, Aller SG, Decker SE, Dawson DC, et al. Mercury and zinc differentially inhibit shark and human CFTR orthologues: involvement of shark cysteine 102. Am J Physiol Cell Physiol. 2006; 290:C793-C801. [PubMed: 16236827]

41. Kaneko H, Kakkar VV, Scully MF. Mercury compounds induce a rapid increase in procoagulant activity of monocyte-like U937 cells. Br J Haematol. 1994; 87:87-93. [PubMed: 7947260]

42. Ahamed J, Versteeg HH, Kerver M, Chen VM, Mueller BM, Hogg PJ, et al. Disulfide isomerization switches tissue factor from coagulation to cell signaling. Proc Natl Acad Sci U S A. 2006; 103:13932-13937. [PubMed: 16959886]

43. Raturi A, Ruf W. Effect of protein disulfide isomerase chaperone activity inhibition on tissue factor activity. J Thromb Haemost. 2010; 8:1863-1865. [PubMed: 20492472]

44. Versteeg HH, Ruf W. Tissue factor coagulant function is enhanced by protein-disulfide isomerase independent of oxidoreductase activity. J Biol Chem. 2007; 282:25416-25424. [PubMed: 17613528]

45. Reinhardt C, von Bruhl ML, Manukyan D, Grahl L, Lorenz M, Altmann B, et al. Protein disulfide isomerase acts as an injury response signal that enhances fibrin generation via tissue factor activation. J Clin Invest. 2008; 118:1110-1122. [PubMed: 18274674]

46. Manukyan D, von Bruehl ML, Massberg S, Engelmann B. Protein disulfide isomerase as a trigger for tissue factor-dependent fibrin generation. Thromb Res. 2008; 122(Suppl 1):S19-S22. [PubMed: 18691493]

47. Kothari H, Sen P, Pendurthi UR, Rao LV. Bovine protein disulfide isomerase-enhanced tissue factor coagulant function: is phospholipid contaminant in it the real culprit? Blood. 2008; 111:3295-3296. [PubMed: 18332231]

48. Persson E. Protein disulfide isomerase has no stimulatory chaperone effect on factor $\mathrm{X}$ activation by factor VIIa-soluble tissue factor. Thromb Res. 2008; 123:171-176. [PubMed: 18550154]

49. Pendurthi UR, Rao LV. Response: Tissue factor de-encryption: the cell model system. Blood. 2008; 112:913.

50. Popescu NI, Lupu C, Lupu F. Extracellular protein disulfide isomerase regulates coagulation on endothelial cells through modulation of phosphatidylserine exposure. Blood. 2010; 116:993-1001. [PubMed: 20448108]

51. Popescu NI, Lupu C, Lupu F. Role of PDI in regulating tissue factor: FVIIa activity. Thromb Res. 2010; 125(Suppl 1):S38-S41. [PubMed: 20163832]

52. Pendurthi UR, Ghosh S, Mandal SK, Rao LV. Tissue factor activation: is disulfide bond switching a regulatory mechanism? Blood. 2008; 112:912-913. [PubMed: 18650465]

53. Bach RR, Monroe D. What is wrong with the allosteric disulfide bond hypothesis? Arterioscler Thromb Vasc Biol. 2009; 29:1997-1998. [PubMed: 19923558]

54. Kothari H, Nayak RC, Rao LV, Pendurthi UR. Cystine 186-cystine 209 disulfide bond is not essential for the procoagulant activity of tissue factor or for its de-encryption. Blood. 2010; 115:4273-4283. [PubMed: 20237315] 
55. Hatahet F, Ruddock LW. Substrate recognition by the protein disulfide isomerases. FEBS J. 2007; 274:5223-5234. [PubMed: 17892489]

56. Hogg PJ. Disulfide bonds as switches for protein function. Trends Biochem Sci. 2003; 28:210 214. [PubMed: 12713905]

57. Chen VM, Hogg PJ. Allosteric disulfide bonds in thrombosis and thrombolysis. J Thromb Haemost. 2006; 4:2533-2541. [PubMed: 17002656]

58. Jurk K, Lahav J, Vana H, Brodde MF, Nofer JR, Kehrel BE. Extracellular protein disulfide isomerase regulates feedback activation of platelet thrombin generation via modulation of coagulation factor binding. J Thromb Haemost. 2011; 9:2278-2290. [PubMed: 21929690]

59. Essex DW, Miller A, Swiatkowska M, Feinman RD. Protein disulfide isomerase catalyzes the formation of disulfide-linked complexes of vitronectin with thrombin-antithrombin. Biochemistry. 1999; 38:10398-10405. [PubMed: 10441134] 


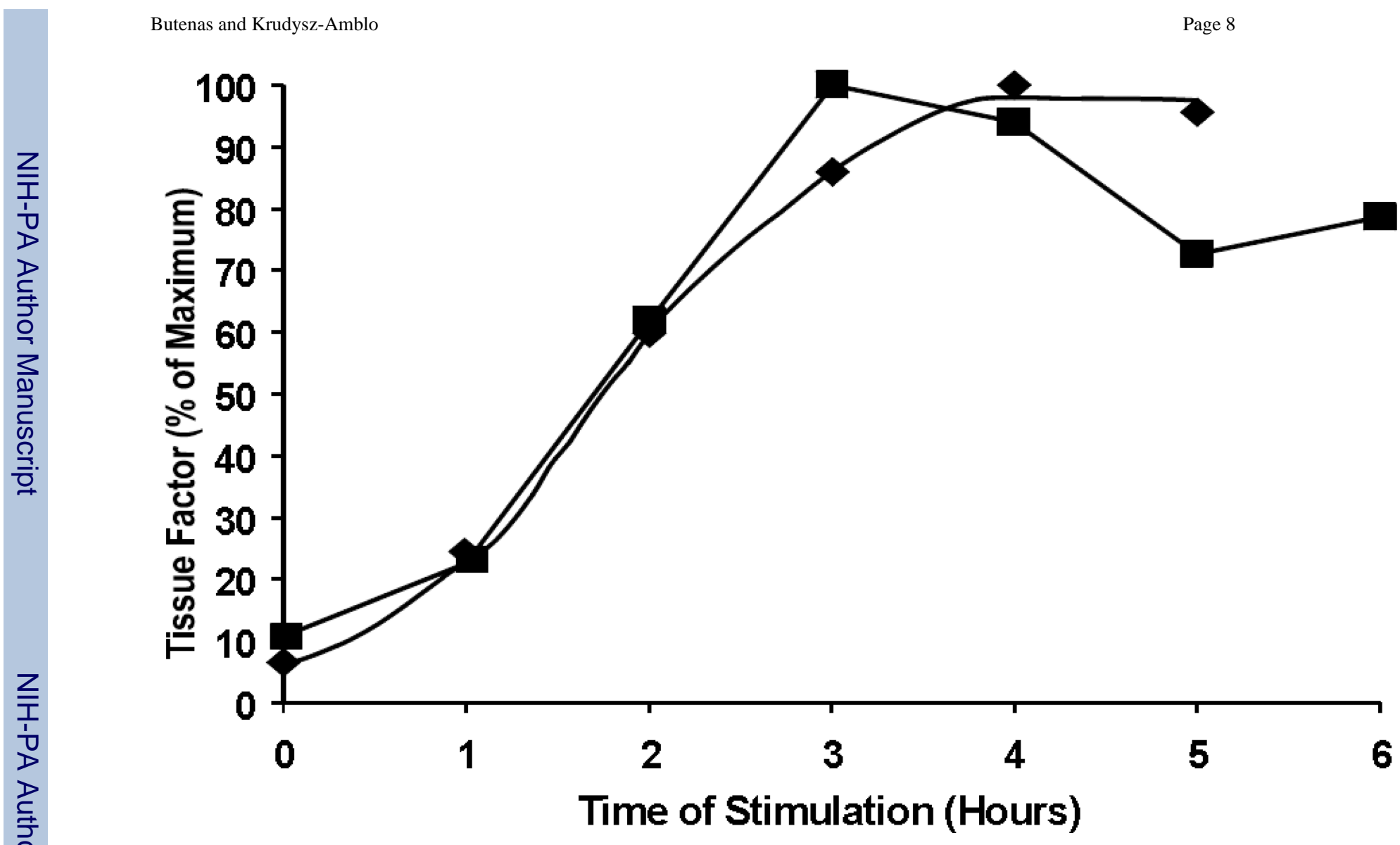

Figure 1.

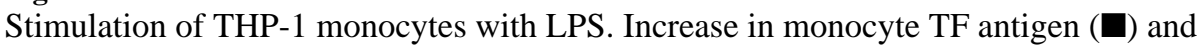
clotting activity ( $)$ over time upon stimulation with $1 \mu \mathrm{g} / \mathrm{mL}$ LPS. 